\title{
19: 1402288-1424237
}

National Cancer Institute

\section{Source}

National Cancer Institute. 19: 1402288-1424237. NCI Thesaurus. Code C41700.

Physical location of APCL_Gene 